\section{Management of Relay-cropped Strawberry and Eggplant to Maximize Yield and Economic Return}

\author{
Ravneet K. Sandhu, Nathan S. Boyd, Shaun Sharpe, Zhengfei Guan, \\ Qi Qiu, Tianyuan Luo, and Shinsuke Agehara \\ Gulf Coast Research and Education Center, University of Florida, Balm, FL \\ 33598
}

Additional index words. Strawberry termination, relay cropping, partial budget analysis, competition

\begin{abstract}
Strawberry growers face rising production costs combined with competition from foreign imports. Relay cropping vegetables with strawberries is a unique approach that can diversify income and reduce the risk associated with strawberry production. Planting vegetable transplants on the same bed before strawberry crop termination enables continued berry harvesting while the new vegetable transplants become established. Relay cropping techniques of strawberry with eggplants were evaluated during the 2016-17 and 2017-18 seasons in Balm, FL. The strawberry crop was planted in September, and eggplant was transplanted into the beds either as a sole crop or with strawberry plants. Two experiments were conducted to optimize the planting date of strawberries and the termination date of strawberries. The objective of the research was to examine the competitive relationship between strawberry and eggplant crops and to define the optimal planting date for the eggplant and termination date of strawberries to minimize the competitive interaction and maximize the yield of both crops. Strawberry yields were unaffected $(P=0.938)$ by relay cropping or by the planting date of the eggplant. Eggplants grown without strawberries had $27 \%$ to $32 \%$ higher yields $(P=$ $0.004)$ compared with relay-cropped eggplants, and eggplant yield decreased with later planting dates $(P<0.001)$. A partial budget analysis showed that transplant dates of 4 and 18 Jan. for eggplants with strawberries resulted in increased profits of $\$ 7320$ and $\$ 3461$ per ha, respectively, over the baseline treatment of strawberries alone, but later planting dates resulted in an overall economic loss $(\mathbf{\$ 7 8 0 0}-\mathbf{\$ 1 6 , 0 0 0 / h a )}$. Strawberry termination dates did not affect eggplant yields. In conclusion, relay cropping eggplants with strawberries resulted in no effect on strawberry yields, reduced eggplant yields, but increased overall profits when eggplant were transplanted in early to mid-January. Relay cropping of strawberries with eggplants in early February to early March is less profitable than a monocrop of strawberries.
\end{abstract}

Modern agriculture is typically focused on monoculture techniques that are often economically and environmentally expensive, have high input costs, and deplete natural resources (Horwith, 2006). Many of the problems associated with monocropping could be minimized by growing two or more different crops together, which is known as intercropping (Karley et al., 2014). Intercropping consists of many different types of production systems (mixed cropping, relay

Received for publication 18 Feb. 2020. Accepted for publication 30 Apr. 2020.

Published online 17 June 2020

We acknowledge the Florida Department of Agriculture and Consumer Services for providing financial support under the Florida Specialty Crop Block Grant Program. We also express gratitude toward the Weed Science laboratory members and Jose Moreno at Gulf Coast Research and Education Center, University of Florida, Balm.

N.S.B. is the corresponding author. E-mail: nsboyd@ ufl.edu.

This is an open access article distributed under the CC BY-NC-ND license (https://creativecommons. org/licenses/by-nc-nd/4.0/). cropping, and strip cropping). Relay cropping involves planting a secondary crop on the bed before the harvesting of the main crop, which results in the overlap of their distinctive life cycles (Queen et al., 2009; Tanveer et al., 2017). Benefits to relay cropping include increased crop productivity, crop diversity, and land-resource use efficiency by using residual fertilizers, reusing plastic mulch and drip irrigation lines, and growing two crops with a single fumigation treatment $(\mathrm{Li}$ and Zhang, 2003; Theunissen, 1997). Relay cropping can enhance the economic return by growing and harvesting two crops in a short period (one season) of time with fewer input costs per crop (Tanveer et al., 2017). However, the established first crop does have a competitive advantage and could impede the second crop (Coolman and Hoyt, 1993). Moreover, relay cropping facilitates a wider range of planting dates/harvesting dates especially for growers practicing contract farming.

In relay cropping, the interspecific competition between the crops becomes a major challenge when two critical growth stages of the crop plants occur at the same time (Coolman and Hoyt, 1993). For example, tomatoes relay cropped with okra had reduced yields compared with monocrop production (Olasantan, 1985). However, relay crops of melons, squash, and cucumber had no effect on strawberry yield, aboveground biomass, or canopy diameter when the strawberries were planted in early October, and secondary crops were transplanted at 15-day intervals from 25 Jan. to 23 Mar. (Santos et al., 2008).

Strawberry is a major winter crop grown on plastic-covered raised beds in Florida. The strawberry growing season extends from September to March, depending on the market (Chandler et al., 2009). Among strawberryproducing states, Florida stands second to California in strawberry production, with an economic value of \$291 million in 2015-16 (USDA/NASS, 2017). However, in recent years, the strawberry market in Florida has faced high production costs, foreign competition, and limited labor availability (Suh et al., 2017). Many growers in the region relay-crop melons (Cucumis melo var. cantalupensis Ser.), eggplants (Solanum melongena L.), and bell peppers (Capsicum annum L.) or other crops into the strawberry crop 3 to 4 weeks before strawberry crop termination (Duval, 2005), to overcome the challenges. Partial economic analysis on annual plasticulture-produced strawberries double-cropped with muskmelons has shown that the second crop can recover $60 \%$ of the strawberry production cost (Poling and Lamont, 1997). Further research is needed to improve this production system.

In Florida, weather events such as low temperature and freezing during the winter months are the primary concerns for scheduling planting dates of the second crop. Eggplant (Solanum melongena L.) is a warmseason Solanaceae fresh-market vegetable and is very sensitive to cold temperatures. In 2007, Florida ranked second in annual eggplant production, and it is commonly planted as a double-crop (USDA-NAAS, 2009). Average minimum temperatures of $10{ }^{\circ} \mathrm{C}$ can reduce total biomass, lower reproductive growth, and decreased fruit weight in eggplants (Romano and Leonardi, 1994). However, to our knowledge there are no studies done on strawberries relay-cropped with tall stature and heavily shading crops like eggplant. Although strawberry plants are shade tolerant (Chandler et al., 1992), the robust and vigorous growth pattern of eggplants could result in excessive shading, belowground competition, and impact yield. Planting date optimization for the second crop is, therefore, a critical consideration for growers. There have been few studies conducted on planting date optimization of cucurbits when relay cropped with strawberries (Santos et al., 2008), but there are no studies reported on strawberry relay cropping with eggplants or other Solanaceae crops.

We hypothesized that eggplants growing with strawberries would have lower yields than the ones planted as a monocrop and that the late planting dates would have higher eggplant yields due to fewer overlapping growth stages. The objectives of the research 
were 1) to evaluate the effect of relay cropping on the yield of strawberries and eggplants, 2) to optimize the planting date of the secondary crop to reduce competition, 3 ) to analyze and compare the economic returns of different treatment, and 4) to determine the effect of strawberry termination date on the yield of the secondary crop.

\section{Materials and Methods}

\section{Experimental setup}

Field experiments were conducted at the research site of University of Florida (Gulf Coast Research and Education Center, Balm $27^{\circ} \mathrm{N}, 82^{\circ} \mathrm{W}$ ), in $2016-17$ and repeated in 2017-18. The soil was Myakka fine sand (sandy, siliceous, hyperthermic Oxyaquic Alorthod) with soil texture comprising of $98 \%$ sand, $1 \%$ silt, and $1 \%$ clay. The soil was composed of $0.8 \%$ organic matter and had a $\mathrm{pH}$ of 5.5 to 6.0 . Standard bed shaping equipment was used to make raised beds with a bed top width of $66 \mathrm{~cm}$ and height of 30.5 cm on 10 Sept. and 15 Aug. in 2016 and 2017 , respectively (Kennco Manufacturing, Ruskin, FL). The beds were fumigated with $63.4 \% 1$, 3 -dichloropropene and $34.7 \%$ chloropicrin (Telone C35; Dow AgroSciences, Indianapolis, IN) at $341 \mathrm{~kg} / \mathrm{ha}$. Drip tape was installed on the surface in the middle of the beds (Jain Irrigation Inc., Haines City, FL) with a flow rate of $0.95 \mathrm{~L} / \mathrm{min}$ and emitters every $30 \mathrm{~cm}$. The beds were covered with black, virtually impermeable film in 2016 and totally impermeable film in 2017 (Berry Plastics Corp., Evansville, IN).

Strawberry (cv. Radiance ${ }^{\mathrm{TM}}$ ) was transplanted on 12 and 10 Oct. in 2016 and 2017, respectively, on 6-m-long plots in two parallel rows with $38 \mathrm{~cm}$ spacing between plants and $30 \mathrm{~cm}$ spacing between rows. Overhead irrigation was applied to protect the strawberry plants from heat stress and better establishment for 10 to $14 \mathrm{~d}$ after the transplant as needed. The nutrient, irrigation, and disease and pest management of both crops followed industry recommendations (Liu et al., 2018; Whitaker et al., 2018). All the fertilizer was applied through drip irrigation system to all the plots.

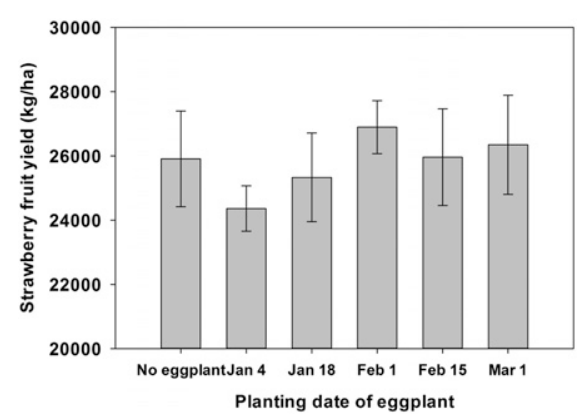

Fig. 1. Strawberry yield on different transplant dates at Gulf Coast Research and Education Center in 2017 and 2018. Data are mean \pm SE of strawberry yield of 2 years pooled together.
In both trials, eggplants (cv. Night Shad$\mathrm{ow}^{\mathrm{TM}}$ ) were transplanted in the middle of the bed, and spacing between plants was kept standard at $76.2 \mathrm{~cm}$ as per University of Florida/Institute of Food and Agricultural Sciences (UF/IFAS) recommendations (Mcavoy et al., 2018). Strawberry plants were ended manually by hand-pulling the plants at the end of the season for both years.

Planting date for the relay crop. The experimental design was a $2 \times 5$ factorial, randomized complete block with four replications, and the experiment was conducted twice. The first factor was the presence or absence of strawberry plants. The second factor was eggplant transplanting dates with five dates: 4 Jan., 18 Jan., 1 Feb., 15 Feb., and 1 Mar., with a nonplanted control in Spring 2017. Transplanting dates for eggplant were delayed by 1 week in 2018 due to severe weather and occurred on 11 Jan., 25 Jan., 8 Feb., 22 Feb., and 8 Mar. The results are presented as an average of 2 years of data.

\section{Land equivalent ratio}

Land equivalent ratio (LER) is calculated to measure the productivity and efficacy of intercropping (Amanullah et al., 2016). LER can be defined as the "sum of the ratio of the yields of crops under intercropping and yields of the sole crop at the same management level" (Seserman et al., 2018).

$$
\begin{aligned}
L E R= & \frac{\text { Yield }(\text { Strawberry }) \text { intercropped }}{\text { Yield }(\text { Strawberry }) \text { monocropped }}+ \\
& \frac{\text { Yield }(\text { eggplant }) \text { intercropped }}{\text { Yield }(\text { eggplant }) \text { monocropped }}
\end{aligned}
$$

Strawberry termination. A randomized complete block with four replications was used, and the experiment was conducted twice. In both the years, eggplants were transplanted into established strawberries on 1 Feb. (as per grower's practices) as a secondary crop. The main treatment effect was the strawberry termination date, conducted at weekly intervals $(7,14,21$, and $28 \mathrm{Feb}$. and 7 Mar., and a nonplanted control). The nonplanted control had only eggplants.

\section{Data collection}

For all experiments, berries were harvested biweekly from the first week of January to the first week of March. Only marketable berries were hand-picked, weighed, and counted at each harvest. Strawberry plant photosynthesis was measured once at the end of the strawberry season in the first week of March with LICOR-6400XT portable photosynthesis system (LICOR Biosciences, Lincoln, NE) to measure the effects of shading when eggplant was at peak canopy size. Two plants per plot were selected randomly, and photosynthesis data were recorded on two leaves per plant. Brix measurements (once in a whole season) were performed on strawberries growing alone and with eggplants with a pocket refractometer (PAL-1; ATAGO Co., LTD., Tokyo, Japan). Seven berries were selected randomly from freshly harvested lot from each treatment and berry juice was squeezed with hand. Two to three drops of berry juice were used to measure the Brix. Eggplant height was recorded every $15 \mathrm{~d}$ after transplanting up to $90 \mathrm{~d}$. Eggplant fruits were hand-picked and weighed once a week from May to the first week of June. The same number of harvests were done for each harvest date to ensure the same number of pickings for each treatment.

\section{Partial budget analysis}

Yield prices. Daily prices collected from the U.S. Department of Agriculture (USDA) Agricultural Marketing Service were used to calculate strawberry and eggplant price per pound. The average price for 5 consecutive years was used because both crops have volatile markets, and prices vary significantly from day to day and year to year. The 2-year average revenue for each treatment was calculated by multiplying price and yield per harvest.

Input costs. Input units costs were largely based on previous work that examined Florida strawberry production costs and trends (Guan et al., 2017). Additional cost estimates were also collected (Food and Resource Economics Department, 2008) and the prices were updated for the 2016-17 year using the Producers Price Index (U.S. Bureau of Labor Statistics, 2016). Eggplant cost was estimated based on a survey among growers (Z.F. Guan and F. Wu, personal communication). The prices of Glyphosate and Gramaxone were collected from local distributors when the experiment was conducted. The standard farm labor wage rate was obtained for farmworkers and laborers, crop, nursery, and greenhouse workers (U.S. Department of Labor, 2017).

Data analysis. Data were analyzed with analysis of variance (ANOVA) using the Glimmix procedure in SAS (Version 9.2; SAS Institute, Inc., Cary, NC). Assumptions of ANOVA were checked. No data transformations were performed. Block and year were considered as a random effect, while the date of planting and presence or absence of a relay crop was considered as a fixed effect. Linear regression analysis was done to analyze the relationship (growth rate) between days after planting and eggplant height using Sigma plot (Systat Software Inc., San Jose, CA). A Student's $t$ test was done to compare the slopes of height (Andrade and Estévez-Pérez, 2014). Mean separation was conducted using Tukey's honestly significant difference test $(\alpha=0.05)$. In the second experiment, the block was considered a random effect and the date of strawberry termination was considered as a fixed effect.

\section{Results}

\section{Planting date for the relay crop}

The season $\times$ planting date $\times$ presence or absence of strawberries interaction was not significant $(P=0.318)$, so the two seasons of data were pooled and analyzed together for all data. 
Strawberry yields. Strawberry yields were unaffected by the presence of a relay crop on all transplant dates $(P=0.938)$ (Fig. 1). Strawberry Brix values $(P=0.945)$ and photosynthesis rate $(P<0.342)$ ranging between 15 and $22 \mu \mathrm{mol} \cdot \mathrm{m}^{-2} \cdot \mathrm{s}^{-1}$ were unaffected by the relay cropping.

Eggplant heights. The presence of strawberries affected the growth rate of eggplants except when they were transplanted on 15 Feb. (Fig. 2). Similarly, further analysis showed that growth rate as measured by plant height of eggplants planted with strawberries at the early planting date (4 Jan.) was higher than mid to late planting dates; however, the results were reversed when eggplants were planted alone on 4 Jan. The eggplants growing without strawberries when planted on 18 Jan. and $1 \mathrm{Feb}$. grew at the same rate, and their growth rate was significantly higher than the eggplants planted on other planting dates.

Eggplant yield. The interaction between the date of the planting of eggplants and the presence/absence of strawberries was not significant $(P=0.1545)$ for eggplant yields. The eggplants relay cropped with strawberries had significantly lower yields than eggplants grown without strawberries $(P=$ 0.0035) (Fig. 3). The date of planting had a significant effect on eggplant yield $(P<$ $0.0001)$. The early eggplant planting dates, 4 Jan. and 18 Jan., resulted in the highest yields of 72,469 and $75,196 \mathrm{~kg} / \mathrm{ha}$, respectively. The mid to late eggplant planting dates (1 Feb., 15 Feb., and 1 Mar.) resulted in lower yields (Fig. 4).

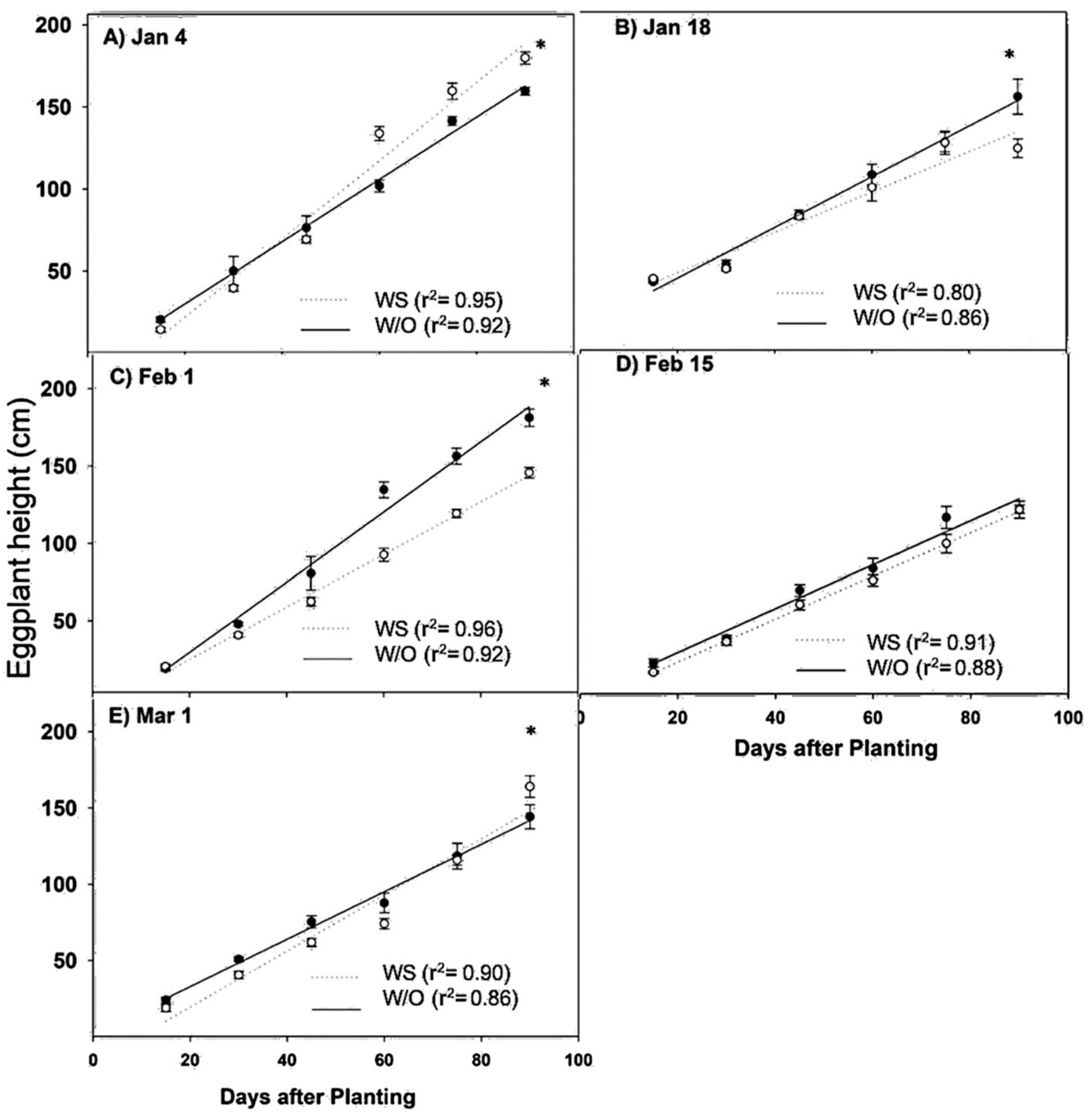

Fig. 2. Eggplant heights (A) 4 Jan., (B) 18 Jan., (C) 1 Feb., (D) 15 Feb., and (E) 1 Mar. at Gulf Coast Research and Education Center in 2017 and 2018 . Data are mean \pm SE (WS = with strawberries and W/OS = without strawberries) with 2 years pooled together recorded at 15, 30, 45, 60, 75, and 90 days after transplanting. *Significant $(P<0.005)$ difference between the slope of eggplant height growing with and without strawberries at a specific date of planting. 


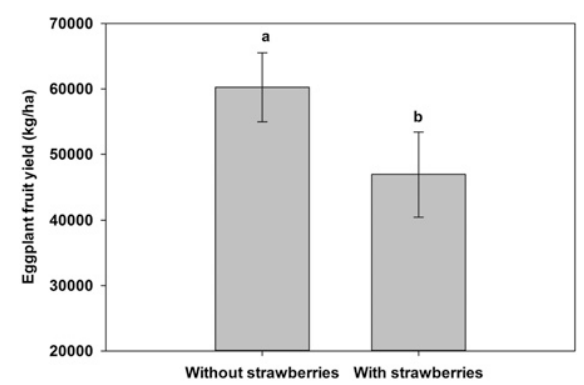

Fig. 3. Overall eggplant yield planted with and without strawberries at Gulf Coast Research and Education Center in 2017 and 2018. Data are mean \pm SE of strawberry yield of 2 years pooled together. Letters above each point denote significant differences $(P<0.05)$

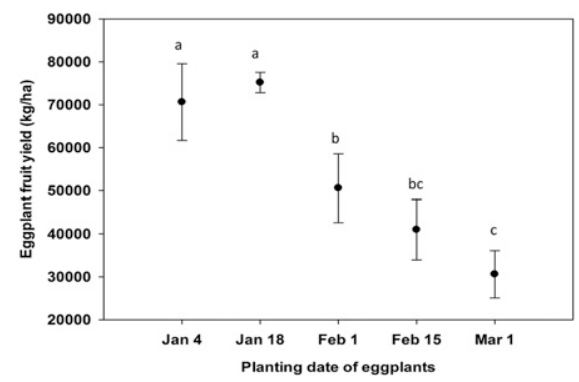

Fig. 4. Eggplant yield averaged across transplant dates at Gulf Coast Research and Education Center in 2017 and 2018. Data are mean \pm SE of strawberry yield of 2 years pooled together. Letters above each point denote significant differences $(P<0.05)$.

Table 1. Land equivalent ratios (LERs) for respective eggplant transplanting dates.

\begin{tabular}{lc}
\hline Eggplant planting date & LER \\
\hline 4 Jan. & 1.69 \\
18 Jan. & 1.62 \\
1 Feb. & 1.78 \\
15 Feb. & 1.89 \\
1 Mar. & 2.19 \\
\hline
\end{tabular}

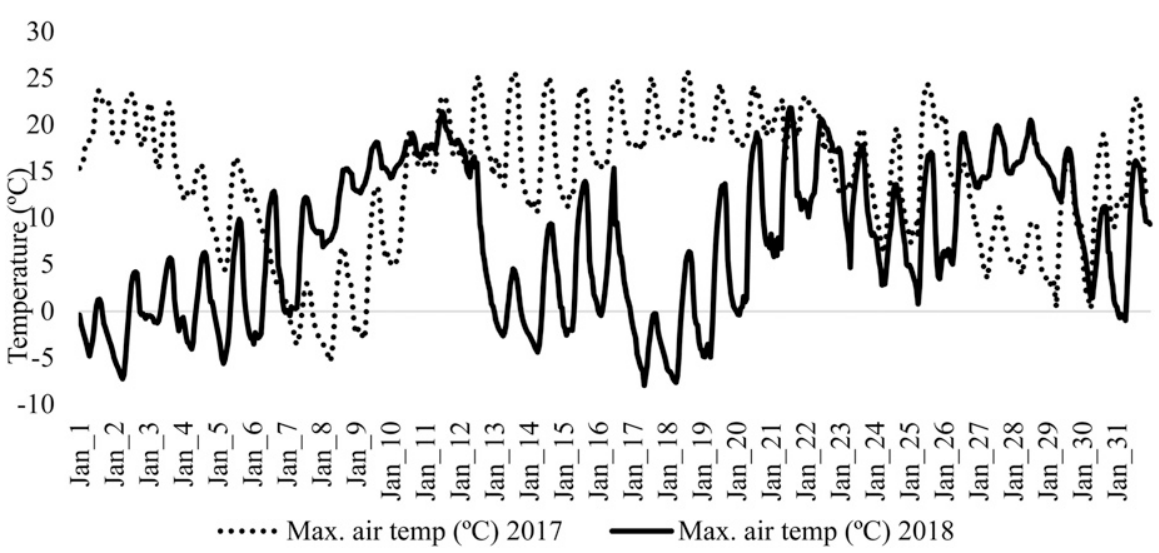

Fig. 5. Daily hourly temperature (at $2 \mathrm{~m}$ ) in January, at Gulf Coast Research and Education Center, Balm, in 2017 and 2018. Max = maximum. (Source: Florida Automated Weather Network, 2017-18).
The number of eggplant fruits was also significantly lower $(P=0.008)$ when planted with strawberries vs. a sole crop with an per hectare, respectively. The date of planting also significantly affected $(P<0.001)$ the number of fruits. However, the interaction between the presence of strawberries and date of planting did not affect $(P=0.336)$ the number of eggplant fruits. Eggplants planted on 18 Jan. had significantly higher fruit numbers followed by eggplants planted on 4 Jan. with an average count of 186,686 and 178,324 fruits per hectare.

Land equivalent ratio. LER value was calculated for every eggplant transplanting date (Table 1).

\section{Strawberry termination}

Strawberry termination date had no effect on eggplant yields and height. As mentioned previously, the major factor that drives crop loss is early season competition or competition duration. Therefore, our results indicate that competition duration had no impact on crop growth and yield. It also suggests that there is no benefit in terms of eggplant yield to end the strawberry crop early to favor eggplant yields. Moreover, leaving the planting holes empty in the plastic by ending the strawberries early could promote weed growth in the planting holes and result in extended competition as well as hinder plastic removal.

Partial budget analysis: net economic revenue analysis. Relay cropping of strawberries with eggplants resulted in net profits with early planting dates. The revenue of $\$ 7320 /$ ha was obtained when eggplants were relay cropped with strawberries on 4 Jan. followed by revenue of $\$ 3461 /$ ha produced by relay-cropped eggplants planted on 18 Jan. with strawberries. There was a $45.7 \%$ decrease in eggplant revenues when eggplants were planted on Jan. 18 with strawberries vs. those that were planted on 4 Jan. due to reduced yields. The eggplants when relay cropped with strawberries at later planting dates (after 1 Feb.) resulted in overall losses (\$6500-\$15,000/ha) compared with average count of 118,818 and 154,210 fruits eggplants planted on early planting dates. Eggplants planted alone on $18 \mathrm{Jan}$. produced revenues of $\$ 6446.6 / \mathrm{ha}$. Eggplants planted alone on all other different planting dates resulted in net losses.

\section{Discussion}

In this study, strawberry yields were unaffected by the presence of eggplants. Similar results were reported in studies performed on strawberries relay cropped with melons, cucumbers, and bell peppers (Santos et al., 2008; Yu et al., 2018). The strawberry crop was planted in early October and was grown as a sole crop during the critical growth period for strawberry, which corresponds to the first 3 months (Duval, 2005; Santos et al., 2008). Eggplant was transplanted after strawberry establishment and did not affect yield because of the lack of early growth stage competition due to the seasonal difference in the planting dates of two crops. Similarly, a study that reported on strawberries planted with sudan-grass for 1 month showed that the early competition reduced strawberry yield by $20 \%$ and that 1 month of interspecific competition at later stages did not affect the strawberry yields (Pritts and Kelly, 2001). Another study on intercropping of strawberries with lettuce, radish, and onions reported having no effect on strawberry yields (Karlidag and Yildirim, 2009). Strawberries are relatively tolerant of shading, with shading having limited effects on berry yields (Chandler et al., 1992).

Relay cropping had no effect on sugar concentrations in the berries. Karlidag and Yildirim (2009) also found that total soluble sugar (Brix \%) in strawberries intercropped with vegetables was the same as strawberries planted as a sole crop. The primary factor determining sugar accumulation in fruits is photosynthesis (Hubbard et al., 2019; Zhou et al., 2000). Given that we did not observe any differences in photosynthesis, it is not surprising that the presence of the relay crop had no effect on sugar accumulation in the fruit.

Weather is a critical variable in the growth and yield of crops. The maximum air temperature in 2017 and 2018 in January dropped below the freezing point $\left(0\right.$ to $\left.5{ }^{\circ} \mathrm{C}\right)$ (Fig. 5) right after eggplant transplant and damaged the eggplants growing without strawberries. In the relay crop, eggplants transplanted with strawberries were protected and shielded against freezing winds by strawberries. Average temperatures below $10^{\circ} \mathrm{C}$ are known to restrict height in crops in the Solanaceae family because of a reduction in internodes formed (number of leaves) (Criddle et al., 1997; Nieuwhof et al., 1997; Van Der Ploeg and Heuvelink, 2005). The eggplants planted in late February and early March had reduced growth rates and height likely because of high average temperature at very early growth stages. The stems of eggplants are very susceptible to sun scalding, especially 5 to $14 \mathrm{~d}$ after transplanting under hightemperature conditions (Orzolek, 2018), 
Table 2. Average maximum and minimum monthly temperature in Balm from January to June in 2017 and 2018. (Source: Florida Automated Weather Network, 2017-18)

\begin{tabular}{|c|c|c|c|c|c|c|}
\hline \multirow[b]{2}{*}{ Month } & \multicolumn{3}{|c|}{2017} & \multicolumn{3}{|c|}{2018} \\
\hline & $\mathrm{T} \operatorname{avg}\left({ }^{\circ} \mathrm{C}\right)$ & $\mathrm{T} \min \left({ }^{\circ} \mathrm{C}\right)$ & $\overline{\mathrm{T} \max \left({ }^{\circ} \mathrm{C}\right)}$ & $\overline{\mathrm{T}} \operatorname{avg}\left({ }^{\circ} \mathrm{C}\right)$ & $\mathrm{T} \min \left({ }^{\circ} \mathrm{C}\right)$ & $\mathrm{T} \max \left({ }^{\circ} \mathrm{C}\right)$ \\
\hline January & 17.3 & 0.1 & 30.0 & 13.5 & -3.8 & 28.0 \\
\hline February & 19.0 & 5.0 & 30.2 & 21.2 & 8.3 & 30.3 \\
\hline March & 19.1 & 1.7 & 31.3 & 17.3 & 2.0 & 29.5 \\
\hline April & 23.1 & 7.6 & 35.7 & 21.8 & 9.3 & 31.5 \\
\hline May & 24.8 & 10.7 & 34.6 & 23.9 & 13.8 & 32.7 \\
\hline June & 25.7 & 20.2 & 34.1 & 26.7 & 19.7 & 34.9 \\
\hline
\end{tabular}

which could affect plant growth and development.

Eggplants planted with strawberries had lower yields than the eggplants planted alone. All plots received the same fertilizer, including the control plots that were empty until January. The increase in yields could possibly be attributed to accumulation of the preplant fertilizer. However, Florida has spodosol soils that are very prone to surface

Table 3. The total cost and revenue comparison between strawberry productions vs. strawberry relay cropped with eggplant. A negative sign indicates reduced costs, returns, and profits compared with strawberries alone.

\begin{tabular}{|c|c|c|c|c|c|c|}
\hline Treatments $^{\mathrm{z}}$ & $\begin{array}{c}\text { Added costs } \\
\text { of the alternative } \\
\text { treatment }(\$ / \mathrm{ha})\end{array}$ & $\begin{array}{l}\text { Reduced returns } \\
\text { of the alternative } \\
\text { treatment }(\$ / \mathrm{ha})\end{array}$ & $\begin{array}{l}\text { Reduced costs } \\
\text { of the alternative } \\
\text { treatment }(\$ / \mathrm{ha})\end{array}$ & $\begin{array}{l}\text { Added returns } \\
\text { of the alternative } \\
\text { treatment }(\$ / \mathrm{ha})\end{array}$ & $\begin{array}{l}\text { Total positive effects } \\
\text { of the alternative } \\
\text { treatment }(\$ / \mathrm{ha})\end{array}$ & $\begin{array}{l}\text { Net effects relative } \\
\text { to baseline } \\
\text { treatment }(\$ / \mathrm{ha})^{\mathrm{y}}\end{array}$ \\
\hline Only strawberries $^{x}$ & 0 & 0 & 0 & 0 & 0 & 0 \\
\hline S+E (4 Jan.) & $38,075.9$ & 0 & 0 & $45,396.6$ & $45,396.6$ & $7,320.6$ \\
\hline $\mathrm{S}+\mathrm{E}(1 \mathrm{Feb})$. & $38,075.9$ & 0 & 0 & $30,262.3$ & $30,262.3$ & $-7,813.6$ \\
\hline $\mathrm{S}+\mathrm{E}(15 \mathrm{Feb})$. & $38,075.9$ & 0 & 0 & $26,301.1$ & $26,301.1$ & $-11,774.8$ \\
\hline S+E (1 Mar.) & $38,075.9$ & 0 & 0 & $22,103.4$ & $22,103.4$ & $-15,972.5$ \\
\hline E (1 Feb.) & 0 & $-71,908.6$ & $-23,580.9$ & $41,858.4$ & $53,361.1$ & $-6,469.3$ \\
\hline E (15 Feb.) & 0 & $-71,908.6$ & $-23,580.9$ & $30,382.5$ & $41,885.2$ & $-17,945.2$ \\
\hline E (1 Mar.) & 0 & $-71,908.6$ & $-23,580.9$ & $19,223.3$ & $30,726.0$ & $-29,104.4$ \\
\hline
\end{tabular}

${ }^{\mathrm{z}}$ Treatments: $\mathrm{S}=$ strawberry; $\mathrm{E}=$ eggplant.

${ }^{\mathrm{y}}$ Net profits were compared with baseline treatment (only strawberries).

${ }^{\mathrm{x}}$ Baseline treatment (only strawberries).

Table 4. The major cost items of the baseline treatments and eggplant treatments. The dashes indicate that there is no difference in cost.

\begin{tabular}{|c|c|c|c|}
\hline Input names & $\begin{array}{l}\text { Strawberry production } \\
\text { costs }(\$ / \mathrm{ha})\end{array}$ & $\begin{array}{l}\text { Change in costs associated with } \\
\text { relay cropped eggplant }(\$ / \mathrm{ha})\end{array}$ & $\begin{array}{c}\text { Differences between baseline and } \\
\text { eggplant-only treatments }(\$ / \mathrm{ha})\end{array}$ \\
\hline Drip tape $\mathrm{e}^{\mathrm{y}}$ & 571.5 & - & - \\
\hline Glyphosate $^{z}$ & 27.5 & - & -27.5 \\
\hline Plastic mulch ${ }^{y}$ & $1,007.3$ & - & $-1,007.3$ \\
\hline Seed and transplants ${ }^{y}$ & $6,811.2$ & - & $-6,811.2$ \\
\hline Fungicide $^{y}$ & $1,594.1$ & - & $-1,594.1$ \\
\hline Fertilizer $^{\mathrm{y}}$ & $3,585.7$ & - & $-3,585.7$ \\
\hline Spraying $^{y}$ & 117.6 & - & -117.6 \\
\hline Tractor: Fuel $\cos ^{\mathrm{y}}$ & $1,638.9$ & - & $-1,638.9$ \\
\hline Tractor: Lubrication $\cos ^{\mathrm{y}}$ & 163.9 & - & -163.9 \\
\hline Cutting, hoeing, and hand weeding & $2,706.5$ & - & $-2,706.5$ \\
\hline Waste disposal ${ }^{y}$ & 287.1 & - & -287.1 \\
\hline Picking (at peak time) $)^{x}$ & $24,586.6$ & - & $-12,508.3$ \\
\hline Disking & 72.0 & - & - \\
\hline Eggplants transplants ${ }^{\mathrm{x}}$ & - & 990.9 & 990.9 \\
\hline Strawberry hand-pull cost ${ }^{\mathrm{x}}$ & - & 563.4 & - \\
\hline Herbicides (eggplant) & - & 120.1 & 120.1 \\
\hline Fungicide and insecticide (eggplant) ${ }^{\mathrm{x}}$ & - & $2,605.1$ & $2,605.1$ \\
\hline Fertilizer (eggplant) ${ }^{\mathrm{x}}$ & - & $2,214.1$ & $2,214.1$ \\
\hline Stake and tie (eggplant) ${ }^{\mathrm{x}}$ & - & $4,324.3$ & $4,324.3$ \\
\hline Tractor: Fuel cost (eggplant) & - & 149.6 & 149.6 \\
\hline Picking (eggplant) ${ }^{\mathrm{x}}$ & - & $18,540.3$ & $18,540.3$ \\
\hline Clean-up (eggplant) & - & $2,626.7$ & $2,626.7$ \\
\hline Packing costs (eggplant) & - & $4,388.6$ & $4,388.6$ \\
\hline Cooling costs (eggplant) & - & $1,544.4$ & $1,544.4$ \\
\hline Total & $63,659.7$ & $38,075.9$ & $-11,502.6$ \\
\hline
\end{tabular}

${ }^{\mathrm{z}}$ Cost collected from local distributors.

${ }^{\mathrm{y}} \mathrm{Guan}$ et al. (2017) and U.S. Bureau of Labor Statistics (2016).

${ }^{\mathrm{x}}$ Cost estimated based on a survey among growers and U.S. Department of Labor. 
leaching (Santos, 2015), which makes the accumulation of preplant fertilizer unlikely. Early interspecific crop competition is very critical in intercropping or relay cropping and is a more likely explanation of the yield difference (O'Donovan et al., 1985). The yield reduction could be attributed to detection of neighboring plants, as was noted in several studies focused on corn and early season weed competition, which found reduced corn yields even without competition for resources (Bosnic and Swanton, 1997). The yield reduction also could be explained by the increased planting density with the addition of the second crop on the same beds, which could lead to higher interplant competition. A study reported that root competition was linearly increased from $5 \%$ to $20 \%$ with increased ratio of number of interplant roots from $1: 1$ to $1: 4$, respectively (Rubio et al., 2001). The plants with shallow root systems like strawberries also have the advantage of higher phosphorus uptake compared with moderately deep root system plants (Rubio et al., 2001), which would affect plant growth.

Another potential explanation for the effect on eggplant growth and yield could be the allelopathic effects of strawberry roots. Strawberry roots are known to produce root exudates like succinic acid, adipic acid, benzoic acid, methyl esters of lactic acid, and $p$-hydroxybenzoic acid (Kitazawa et al., 2005). These root exudates are known to be auto toxic and could also affect the growth of companion plants. The plants with shallow root systems like strawberries also have the advantage of higher phosphorus uptake compared with moderately deep root system plants (Rubio et al., 2001), which would affect plant growth.

The air temperature was high, greater than $29.4{ }^{\circ} \mathrm{C}$, during April, May, and June, which overlaps with the flowering stage of eggplants planted on 15 Feb. and 1 Mar. (Table 2). High temperatures $\left(>29.4^{\circ} \mathrm{C}\right)$ have been shown to decrease the percentage of fruit set in another Solanaceae crop, such as tomatoes (Sato et al., 2000) and may explain the reduced yield observed in this trial. In 2018, during the month of March, the mean average temperature dropped to $10^{\circ} \mathrm{C}$, which hampered the growth of freshly transplanted eggplant seedlings (15 Feb. and 1 Mar. planting dates). Criddle et al. (1997) explained that temperatures below $11.6{ }^{\circ} \mathrm{C}$ could cease growth and result in no growth of tomato plants.

Similarly, the eggplant vegetative growth was affected by lower temperatures, which could have resulted in lower fruit yields. However, there are no known peerreviewed studies that examine planting date optimization for eggplant production in Florida. Furthermore, eggplant yields and heights do not strongly correlate with each other. However, the later planting dates (15 Feb. and 1 Mar.) resulted in the lowest yields with shorter plants. The eggplants planted earlier in the season were protected by strawberry plants, hence, resulted in better yields com- pared with later planting dates. This may have been caused by the harsh weather conditions at the end of spring season.

Relay cropping of eggplants at early planting dates resulted in higher economic returns (Table 3 ). The total production cost of the strawberry (baseline treatment), including fumigation, plastic mulch, drip tape, bed preparation, transplant, crop management, harvest, and post-harvest costs was $\$ 49,789$. Some of the management costs $(\approx \$ 13,000$ / ha) can be distributed between the strawberry and eggplant crops, such as the cost of bed preparation, the plastic used to cover the beds, soil fumigation, fertilizer, and pesticide cost. Relay cropping does incur some additional costs associated with hand-pulling of strawberry plants of $\$ 563 /$ ha. Relay cropping eggplants does add significant costs associated with pesticide inputs, staking/tying, and harvest of $\$ 2605, \$ 4324$, and $\$ 18,540 / \mathrm{ha}$, respectively (Table 4$)$. Therefore, crop yields need to be adequate to cover these costs to ensure additional income is acquired.

As a result, the production costs of relay cropping eggplants with strawberry was $\$ 36,952 /$ ha higher than the baseline treatment of strawberries alone. However, the production costs of treatments in which eggplants were planted alone were $\$ 10,816 /$ ha less than the baseline treatment (Table 4) because of the lack of strawberry production costs. Major cost differences are associated with postharvest management of both the crops in case of relay cropping of strawberries with eggplants. The strawberry packing and cooling costs were $83 \%$ and $81 \%$ higher when compared with packing and cooling of eggplants, respectively. The high production cost of eggplants makes it an expensive and lowrevenue crop to grow if planted alone. However, relay cropping eggplants with strawberries on optimum planting dates distributes the production costs between two crops. It is important to note, however, that the date of planting of the secondary crop is very important, and relay cropping does not always result in improved economic returns (Ott et al., 2019).

LER values of more than 1 suggested that relay cropping of eggplants resulted in higher land-resource use efficiency. Overall, it is beneficial to relay crop strawberries with eggplants without affecting strawberry yields with the highest eggplant yields obtained with early planting dates. However, there could be variability in yields and profits depending on the weather conditions.

\section{Conclusion}

Strawberry yield was unaffected by relay cropping. Eggplants relay cropped with strawberry generally had lower yields than eggplants grown alone. However, when eggplants were planted on 4 and 18 Jan., the yields were high enough to cover the increased cost associated with relay cropping and increase overall profit per hectare than planting two crops at the same bed at different times. Conversely, relay cropping of eggplants with strawberries resulted in economic losses when eggplant transplanting was done later in the season. The eggplants grown by themselves resulted in losses at all the planting dates. We conclude that relay cropping is economically beneficial only when eggplant yields are adequate to offset increased production costs, which occurred when they were transplanted early in the season, but lower yields associated with later planting dates can lead to economic losses.

\section{Literature Cited}

Amanullah, F.K., H. Muhammad, A.U. Jan, and G. Ali. 2016. Land equivalent ratio, growth, yield and yield components response of mono-cropped vs. inter-cropped common bean and maize with and without compost application. Agr. Biol. J. North America 7:40-49.

Andrade, J.M. and M.G. Estévez-Pérez. 2014. Statistical comparison of the slopes of two regression lines: A tutorial. Anal. Chim. Acta 838:1-12.

Bosnic, A.C. and C.J. Swanton. 1997. Influence of barnyardgrass (Echinochloa crus-galli) time of emergence and density on corn (Zea mays). Weed Sci. 45:276-282.

Chandler, C.K., D.D. Miller, and D.C. Ferree. 1992. Shade during July and August reduces growth but not fruiting of strawberry plants. HortScience 27:1044.

Chandler, C.K., N.A. Peres, V.M. Whitaker, H.A. Smith, and S.P. Brown. 2009. Growing strawberries in the Florida home garden. University of Florida IFAS Extension. Publication \#HS1154.

Coolman, R.M. and G.D. Hoyt. 1993. Increasing sustainability by intercropping. HortTechnology 3:309-312.

Criddle, R.S., B.N. Smith, and L.D. Hansen. 1997. A respiration based description of plant growth rate responses to temperature. Planta 201:441-445.

Duval, J.R. 2005. Relay-intercropping does not reduce strawberry yield in an Annual-hill production system. HortTechnology 15:907-908.

Florida Automated Weather Network. 2017-18. $<$ https://fawn.ifas.ufl.edu/>.

Food and Resource Economics Department. 2008. Strawberries: Estimated production costs in the Plant City area. University of Florida.

Guan, Z., F. Wu, and A. Whidden. 2017. Florida Strawberry Production Cost and Trend. Univ. Florida Inst. Food Agr. Sci. Publ. 1-6.

Horwith, B. 2006. A role for intercropping in modern agriculture. Bioscience 35:286-291.

Hubbard, N.L., D.M. Pharr, and S.C. Huber. 2019 Sucrose metabolism in ripening muskmelon fruit as affected by leaf area. J. Amer. Soc. Hort. Sci. 115:798-802.

Karley, A.J., P.J. White, T.J. Daniell, F. Zhang, C. Schöb, R.J. Pakeman, C. Hawes, G. Squire, E. Paterson, C.A. Watson, W.-F. Cong, P.D. Hallett, P.P.M. Iannetta, T.S. George, H.G. Jones, C. Zhang, A.E. Bennett, L. Li, J. Zhang, B.M. McKenzie, J. Shen, and R.W. Brooker 2014. Improving intercropping: A synthesis of research in agronomy, plant physiology and ecology. New Phytol. 206:107-117.

Karlidag, H. and E. Yildirim. 2009. Strawberry intercropping with vegetables for proper utilization of space and resources. J. Sustain. Agr. $33: 107-116$

Kitazawa, H., T. Asao, T. Ban, M.H.R. Pramanik, and T. Hosoki. 2005. Autotoxicity of root exudates from strawberry in hydroponic culture. J. Hort. Sci. Biotechnol. 80:677-680. 
Li, L. and F. Zhang. 2003. Using competitive and facilitative interactions in intercropping systems enhances crop productivity and nutrientuse efficiency. Plant Soil 248:305-312.

Liu, G., E.H. Simonne, K.T. Morgan, G.J. Hochmuth, and M. Ozores-hampton. 2018. Fertilizer management for vegetable production in Florida. Veg. Prod. Handb. Florida. Univ. Florida, IFAS Extension, Gainesville, FL.

McAvoy, E.J., N.S. Boyd, P.D. Roberts, J. Desaeger, J.W. Noling, and J. Qureshi. 2018. Chapter 8. Eggplant production, p. 85-111. In: P. Dittmar, J. Freeman, M. Paret, and H. Smith (eds.). Vegetable production handbook of Florida. AgNet Media, Gainesville, FL.

Nieuwhof, M., L.C.P. Keizer, and J.C. Van Oeveren. 1997. Effects of temperature on growth and development of adult plants of genotypes of tomato (Lycopersicon esculentum Mill.). J. Genet. Breed. 51:185-193.

O’Donovan, J.T., E.A. de St. Remy, P.A. O'Sullivan, D.A. Dew, and A.K. Sharma. 1985. Influence of the relative time of emergence of wild oat (Avena fatua) on yield loss of barley (Hordeum vulgare) and wheat (Triticum aestivum). Weed Sci. 33: 498-503.

Olasantan, F.O. 1985. Effects of intercropping, mulching and staking on growth and yield of tomatoes. Exp. Agr. 21:135-144.

Orzolek, M.D. 2018. Establishment of vegetables in the field. HortTechnology 1:78-81.

Ott, M.A., C.A. Eberle, M.D. Thom, D.W. Archer, F. Forcella, R.W. Gesch, and D.L. Wyse. 2019. Economics and agronomics of relay-cropping pennycress and Camelina with Soybean in Minnesota. Agron. J. 111:1281-1292.

Poling, E.B. and W.J. Lamont, Jr. 1997. A partial economic analysis of double-cropping annual hill plastic mulch strawberries with muskmelons. Adv. Strawb. Prod. 10:60-62.
Pritts, M.P. and M.J. Kelly. 2001. Early season weed competition reduces yield of newly planted matted row strawberries. HortScience 36:729-731.

Queen, A., H. Earl, and W. Deen. 2009. Light and moisture competition effects on biomass of red clover underseeded to winter wheat. Agron. J. 101:1511-1521.

Romano, D. and C. Leonardi. 1994. The responses of tomato and eggplant to different minimum air temperatures. Acta Hort. 366:57-64.

Rubio, G., T. Walk, Z. Ge, X. Yan, H. Liao, and J.P. Lynch. 2001. Root gravitropism and below-ground competition among neighbouring plants: A modelling approach. Ann. Bot. 88:929-940.

Santos, B.M. 2015. Future nutrient management in berry crops, p. 150-157. In: M. Pritts, C. Heidenreich, L. McDermott, and J. Miller (eds.). Berry soil and nutrient management A guide for educators and growers. Cornell University, Ithaca, NY.

Santos, B.M., C.E. Esmel, S. Slamova, and E.A Golden. 2008. Optimum planting dates for intercropping cucumber, squash, and muskmelon with strawberry. HortTechnology 18: 2-5.

Sato, S., M.M. Peet, and J.F. Thomas. 2000. Physiological factors limit fruit set of tomato ( $\mathrm{LyCO}-$ persicum esculentum Mill.) under chronic mild heat stress. Plant Cell Environ. 23:719-726.

Seserman, D., M. Veste, D. Freese, A. Swieter, and M. Langhof. 2018. Benefits of agroforestry systems for land equivalent ratio - case studies in Brandenburg and Lower Saxony, Germany. Agroforestry as Sustainable Land Use, At Nijmegen, The Netherlands 3:26-29.

Suh, D.H., Z. Guan, and H. Khachatryan. 2017. The impact of Mexican competition on the U.S strawberry industry. Intl. Food Agribus. Manag. Rev. 20:591-604.
Tanveer, M., S.A. Anjum, S. Hussain, A. Cerdà, and U. Ashraf. 2017. Relay cropping as a sustainable approach: Problems and opportunities for sustainable crop production. Environ. Sci. Pollut. Res. Intl. 24:6973-6988.

Theunissen, J. 1997. Intercropping in field vegetables as an approach to sustainable horticulture. Outlook Agr. 26:95-99.

U.S. Bureau of Labor Statistics. 2016. Producers Price Index. Occupational Outlook Handbook.

U.S. Department of Labor. 2017. Occupational employment and wages. HeinOnline.

USDA-NAAS. 2009. 2007 Census of Agriculture: National, State and County Tables. National Agricultural Statistics Service.

USDA-NASS. 2017. U.S. Department of Agriculture. National agricultural statistics servicedata and statistics. <https://www.nass.usda.gov/ Publications/Ag_Statistics/2017/index.php>.

Van Der Ploeg, A. and E. Heuvelink. 2005. Influence of sub-optimal temperature on tomato growth and yield: A review. J. Hort. Sci. Biotechnol. 80:652-659.

Whitaker, V.M., N.S. Boyd, N.A. Peres, J.W. Noling, and J. Renkema. 2018. Strawberry production cultivars. Veg. Prod. Handb. Florida. Univ. Florida, IFAS Extension, Gainesville, FL.

Yu, J., N.S. Boyd, and Z. Guan. 2018. Relay-cropping and fallow programs for strawberry-based production system: Effects on crop productivity and weed control. HortScience 53:445450 .

Zhou, L., D.A. Christopher, and R.E. Paull. 2000. Defoliation and fruit removal effects on papaya fruit production, sugar accumulation, and sucrose metabolism. J. Amer. Soc. Hort. Sci. 125:644-652. 